Research article

urn:lsid:zoobank.org:pub:D7888701-184A-403C-A150-BF7A908DF737

\title{
Ufocandona hannaleeae gen. et sp. nov. (Crustacea, Ostracoda) from an artesian well in Texas, USA
}

\section{Okan KÜLKÖYLÜOĞLU ${ }^{1, *}$, Mehmet YAVUZATMACA², Derya AKDEMIR ${ }^{3}$, Benjamin F. SCHWARTZ ${ }^{4} \&$ Benjamin T. HUTCHINS ${ }^{5}$}

\footnotetext{
${ }^{1,2}$ Department of Biology, Faculty of Arts and Science, Abant İzzet Baysal University, Bolu, Turkey.

${ }^{3}$ Merdivenköy Mah. Şair Arşi Cad. No:16/14, 34732, Kadıköy, İstanbul, Turkey.

${ }^{4}$ Edwards Aquifer Research and Data Center, Texas State University, San Marcos, TX 78666, USA.

${ }^{4}$ Department of Biology, Texas State University, San Marcos, TX 78666, USA.

${ }^{5}$ Texas Parks and Wildlife Department, 4200 Smith School Road, Austin, TX 78744, USA.
}

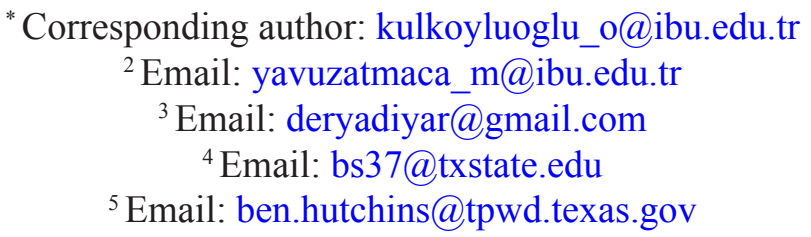

\footnotetext{
${ }^{1}$ urn:1sid:zoobank.org:author:6F 190152-44D5-42FF-98B5-E575DA2D065B

${ }^{2}$ urn:1sid:zoobank.org:author:36CEC965-2BD7-4427-BACC-2A339F253908

${ }^{3}$ urn:1sid:zoobank.org:author:BD420D2B-A808-46FA-A2A0-97D6B13D3E8E

${ }^{4}$ urn:1sid:zoobank.org:author:609C0760-DDFA-44D8-B4A2-4C81FE71AC61

${ }^{5}$ urn:lsid:zoobank.org:author:69FCCCF9-B899-4C9E-8CB3-C2701E74D774
}

\begin{abstract}
We describe a new genus, Ufocandona gen. nov. with its type species Ufocandona hannaleeae gen. et sp. nov., from an artesian well in San Marcos, Texas, USA. The new genus has diagnostic characteristics that distinguish it from other genera in Candonidae, including the asymmetric shape of the valves, the smooth central area on the external surface of the valves, the hexagonal ornamentations around the marginal ends of the carapace, the dense spines on the marginal edges of the right valve and the dorsal prolongation and tubercles seen from inside the ventral edges of the left valve. Additional differences in the soft body parts of the male and female (e.g., claw-like uropod, shape of hemipenis, long $\mathrm{Y}$ aesthetascs, two short or reduced exopods on antenna, reduced numbers of setae and segments on other extremities) distinguish the new genus from others in the family. The discovery of this species from a deep artesian well contributes important information to our understanding of groundwater species diversity in a biologically diverse aquifer where the ostracod fauna has been unstudied.
\end{abstract}

Keywords. Taxonomy, stygobiont fauna, phreatic groundwater, Edwards Aquifer, Texas.

Külköylüoğlu O., Yavuzatmaca M., Akdemir D., Schwartz B.F. \& Hutchins B.T. 2017. Ufocandona hannaleeae gen. et sp. nov. (Crustacea, Ostracoda) from an artesian well in Texas, USA. European Journal of Taxonomy 372: 1-18. https://doi.org/10.5852/ejt.2017.372 


\section{Introduction}

The family Candonidae, a large family with a cosmopolitan distribution (Danielopol et al. 2011), is represented by three subfamilies (Paracypridinae Sars, 1923; Cyclocypridinae Kaufmann, 1900; Candoninae Kaufmann, 1900). The largest subfamily is Candoninae, having about 511 species worldwide (Martens \& Savatenalinton 2011). Prior to this study, Candoninae included about 45 genera (Külköylüoğlu et al. 2011, 2017; Martens \& Savatenalinton 2011; Smith 2011; Danielopol et al. 2012; Higuti \& Martens 2012; Karanovic 2013). In terms of North American Candoninae (Karanovic 2006; Külköylüoğlu et al. 2011, unpublished data), there are at least 42 species in eight genera (Candona Baird, 1845; Typhlocypris Vejdovský, 1882; Paracandona Hartwig, 1899; Candonopsis Vávra, 1891; Eucandona Daday, 1900; Nannocandona Ekman, 1914; Fabaeformiscandona Krstić, 1972; Bicornucandona Külköylüoğlu et al., 2011).

However, based on a recent redefinition of the genus Typhlocypris by Namiotko et al. (2014), all the North American species of this genus listed by Karanovic (2006) should be assigned to the genus Pseudocandona Kaufmann, 1900. Twenty-seven of the 42 species are endemic to North America (Karanovic 2006; Külköylüoğlu et al. 2011).

Artesian wells intersect confined aquifers that are under pressure, causing water to rise up the well and above the aquifer. These wells may provide access to habitat for a diversity of taxa with different ecological niches (Hutchins et al. 2014, 2016). Indeed, studies have shown that artesian wells can harbor endemic and rare species (Krömmelbein 1975; Holsinger \& Longley 1980; Ponder 2004; Külköylüoğlu 2009) and represent some of the most biodiverse groundwater sites on Earth (Culver \& Pipan 2009).

The aims of this study are to introduce the first description of a new genus (Ufocandona gen. nov.) with a new species (Ufocandona hannaleeae gen. et sp. nov.) from Texas, North America and to underline the importance of artesian wells as a window into the biodiversity of deep confined aquifers.

\section{Material and methods}

Site description: The San Marcos Artesian Well (SMAW) (San Marcos, Texas, USA) is a site known for its stygobiontic diversity, which has been periodically sampled and studied since its construction in 1895. The well was completed in the confined zone in a relatively shallow portion of the San Antonio Pool of the Edwards Aquifer. At approximately $59.5 \mathrm{~m}$ depth, the well intersects a $1.5 \mathrm{~m}$ tall conduit (Holsinger \& Longley 1980), from which most of the water and biological materials are presumed to discharge. Water quality is generally high at the site, which has been dye traced to San Marcos Springs (Fig. 1), less than $1 \mathrm{~km}$ to the northeast (see details in Ogden et al. 1986). In November 2013, water temperature at the well averaged $22.3^{\circ} \mathrm{C}(\mathrm{SD} \pm 0.01)$, dissolved oxygen averaged $5.3 \mathrm{mg} / 1(\mathrm{SD} \pm 0.01)$ and electrical conductivity averaged $608 \mu \mathrm{S} / \mathrm{cm}(\mathrm{SD} \pm 0.50)$.

Individuals of the new species were sorted from composite samples collected in a drift-net $(100 \mu \mathrm{m}$ aperture) over the well outflow pipe. Each sample integrated discharged biological materials for 24-96 hours, depending on the sample, and was sorted under a microscope to separate all invertebrates from detritus, most of which is filamentous microbial growth. All samples were preserved in $95 \%$ ethanol. Individual ostracods were measured and dissected in lactophenol solution under a stereo microscope. Carapaces were stored in micropaleontological slides (see below). Carapace and valve images (and some soft body parts) were taken with a scanning electron microscope (JEOL 6335 F SEM) after wet ostracod samples were prepared with hexamethyldisilazane as a drying agent at TÜBİTAK-MAM Institute (Turkey). Additional SEM photographs were also taken at Analysis Research Service Center, Texas State University (USA). A camera lucida (Olympus U-DA) attached to an Olympus BX-51 microscope was used to draw the soft body parts, and an Intuos 5 tablet (Wacom) and Illustrator CS5 (Adobe) 
were later used to digitize drawings. Descriptions of the chaetotaxy of the limbs and the taxonomic status of the genus primarily follow Broodbakker \& Danielopol (1982), Martens (1987), Meisch (2000) and Karanovic (2005a, 2005b, 2012, 2013). All material is deposited at the Limnology Laboratory, Department of Biology, Abant İzzet Baysal University, Bolu, Turkey and lot numbers are preceded by OK-TX-AW = Okan Külköylüoğlu-Texas-Artesian Well.

\section{Abbreviations}

$$
\begin{array}{ll}
\mathrm{A} 1 & =\text { first antenna (antennula) } \\
\mathrm{A} 2 & =\text { second antenna (antenna) } \\
\mathrm{G} 1-\mathrm{G} 3 & =\text { terminal claws of A2 } \\
\mathrm{Gm} & =\text { terminal claw of A2 } \\
\mathrm{GM} & =\text { terminal claw of A2 } \\
\mathrm{H} & =\text { height } \\
\mathrm{L} & =\text { length } \\
\mathrm{LV} & =\text { left valve } \\
\mathrm{Md} & =\text { mandibula } \\
\mathrm{Mxl} & =\text { maxillula } \\
\mathrm{RV} & =\text { right valve } \\
\mathrm{SD} & =\text { standard deviation }
\end{array}
$$

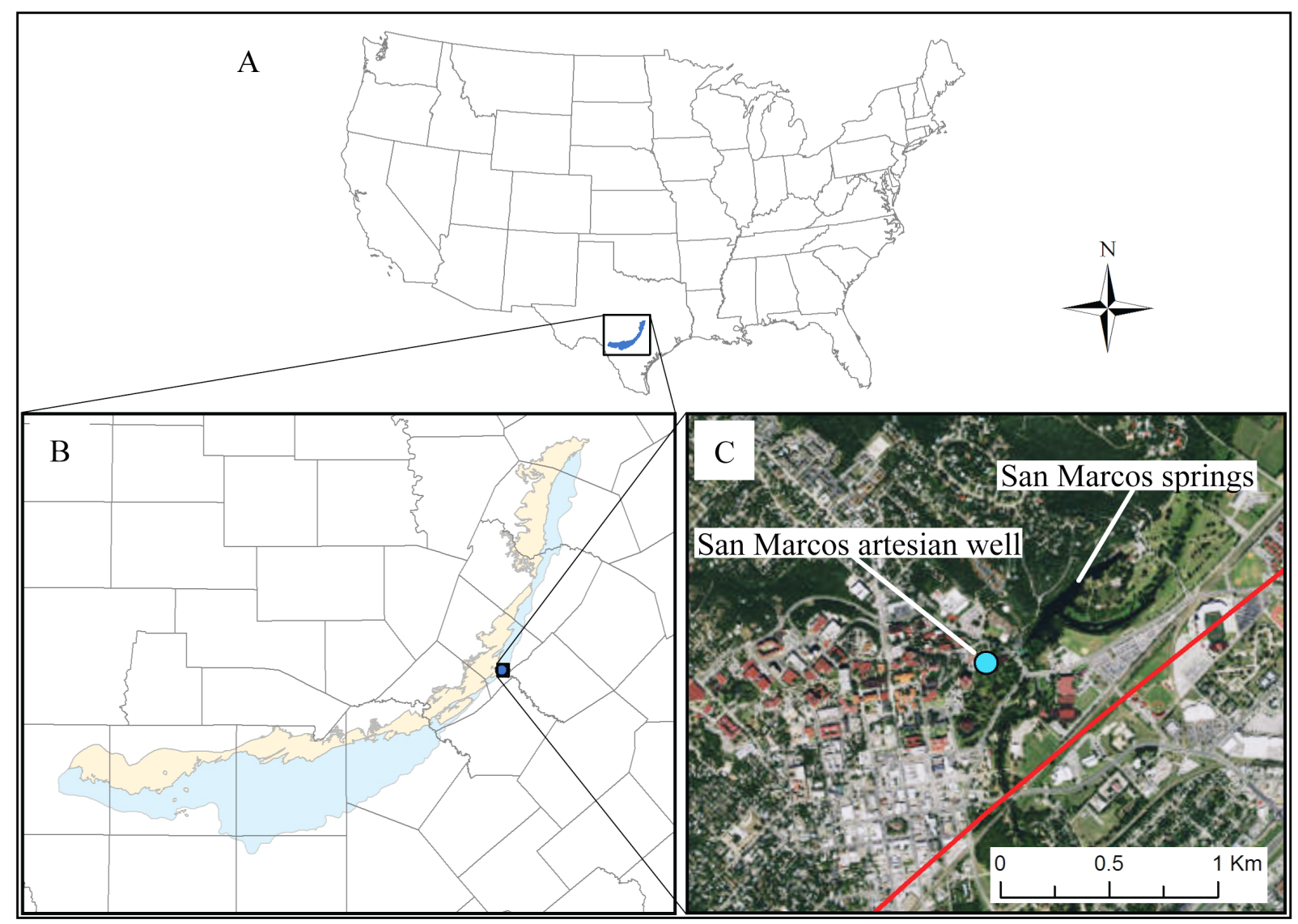

Fig. 1. Type locality for Ufocandona hannaleeae gen. et sp. nov. A. The Edwards Aquifer (in blue). B. The unconfined (tan) and confined (blue) portions of the Edwards Aquifer. C. The city of San Marcos, the San Marcos artesian well, and San Marcos springs. Red line shows approximate boundary of the freshwater-saline water interface. 


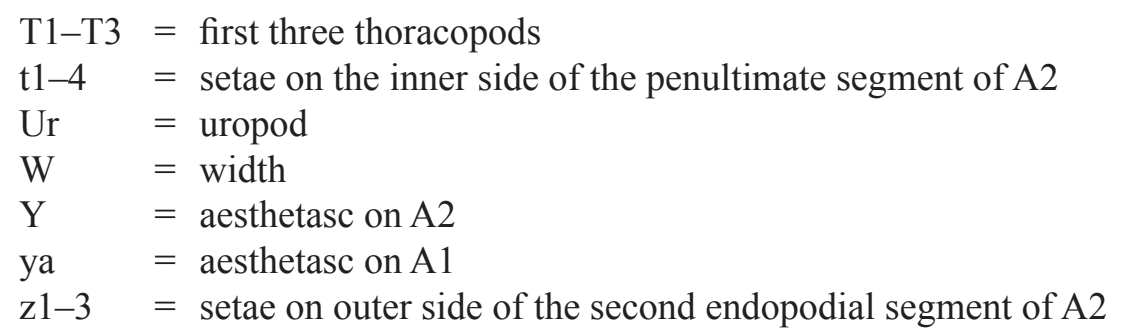

\section{Results}

Class Ostracoda Latreille, 1802

Order Podocopida Sars, 1866

Suborder Cypridocopina Baird, 1845

Superfamily Cypridoidea Baird, 1845

Family Candonidae Kaufmann, 1900

Subfamily Candoninae Kaufmann, 1900

Genus Ufocandona gen. nov.

urn:1sid:zoobank.org:act:5E64ABC9-C598-4A4B-B257-C92053E419FD

\section{Type species}

Ufocandona hannaleeae gen. et sp. nov. (genus presently monotypic).

\section{Diagnosis}

In lateral view, carapace strongly asymmetrical: RV sub-triangular, dorsal margin sloping posteriorly; LV rounded, overlapping RV (Figs 2A-F, 7A-B). Only known species small $(<0.5 \mathrm{~mm})$. LV with prolongation (flange) extending dorsally (Fig. 2A-B, E). RV with thin spines around marginal zone, except hinge (Fig. 2C-D). Maximum height just anterior to center. In dorsal view (Figs 3A, 7B), carapace laterally tumid, greatest width around center, both ends laterally compressed, beak-shaped (Fig. 7B). Hinge adont. Valve surface slightly smooth at center, but ornamented with semi-hexagonal structures around marginal zones. Shallow pits common in both sexes and juveniles. Central muscle scars not visible on valve surface (Fig. 2), but two dorsal muscle scars present medio-dorsally (Figs 2E, 3C-E). Two inner lists present on inner lamella (Fig. 2E). Anterior and posterior marginal areas of LV with 5-6 and 3-4 round tubercles on first list, respectively. Second list shorter than first one. Calcified inner lamella (duplicature) about similar in width anteriorly and posteriorly. Uncalcified inner lamella wide.

A1 8-segmented. A2 4-segmented in both sexes. Exopod with two very short setae in males and all claws (G1-3, GM, Gm) present on A2 of females. Swimming (natatory) setae absent, as in all Candoninae. Setae t1-4 absent on A2 (diagnostic character).

Md-palp 4-segmented, without alpha, beta or gamma setae (diagnostic character). Mxl palp long, with $2+2$ well developed smooth setae; two setae extending from apical corner of first segment, and two (one shorter) on terminal segment.

T1 modified into clasping organs in males. T2 5-segmented, with one well developed d1 seta. T3 4-segmented, with one seta (d1) on first segment (protopodite). Uropod with thin, spine-like terminal seta (diagnostic character). Hemipenis with rounded medial lobe (h), inner lobe (b) spatula-shaped, outer lobe (a) with triangular end pointing ventrally (diagnostic character). M-process faintly seen, part-g strongly curved. Zenker organ with $4+2$ rings of spines. 


\section{Etymology}

The acronym UFO is combined with the generic name Candona as Ufocandona, referencing the similarity of the carapace to the stereotypic "flying saucer" shape of "Unidentified Flying Objects".
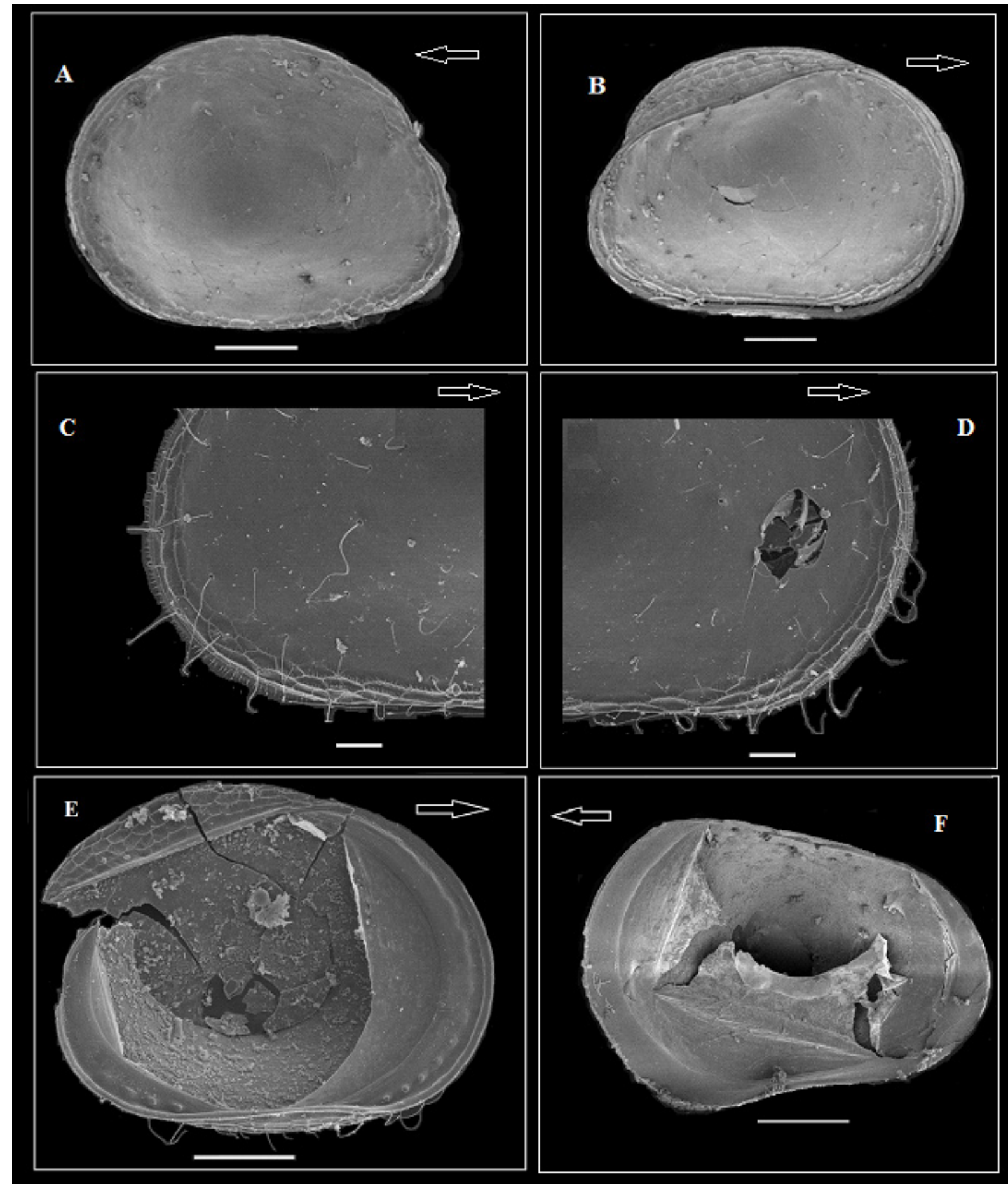

Fig. 2. Ufocandona hannaleeae gen. et sp. nov. A. LV of $q$, external view. B. RV of $\widehat{\partial}$, external view. C. Posterior end of RV with spines in $\widehat{\partial}$. D. Anterior end of RV in $\widehat{\partial}$ (note broken part). E. LV of $O$ with tubercles, internal view (note broken part in the center). F. RV of $\hat{\partial}$, internal view. Arrows indicate anterior end. Scale bars: A-B, E-F $=100 \mu \mathrm{m} ; \mathrm{C}-\mathrm{D}=20 \mu \mathrm{m}$. 

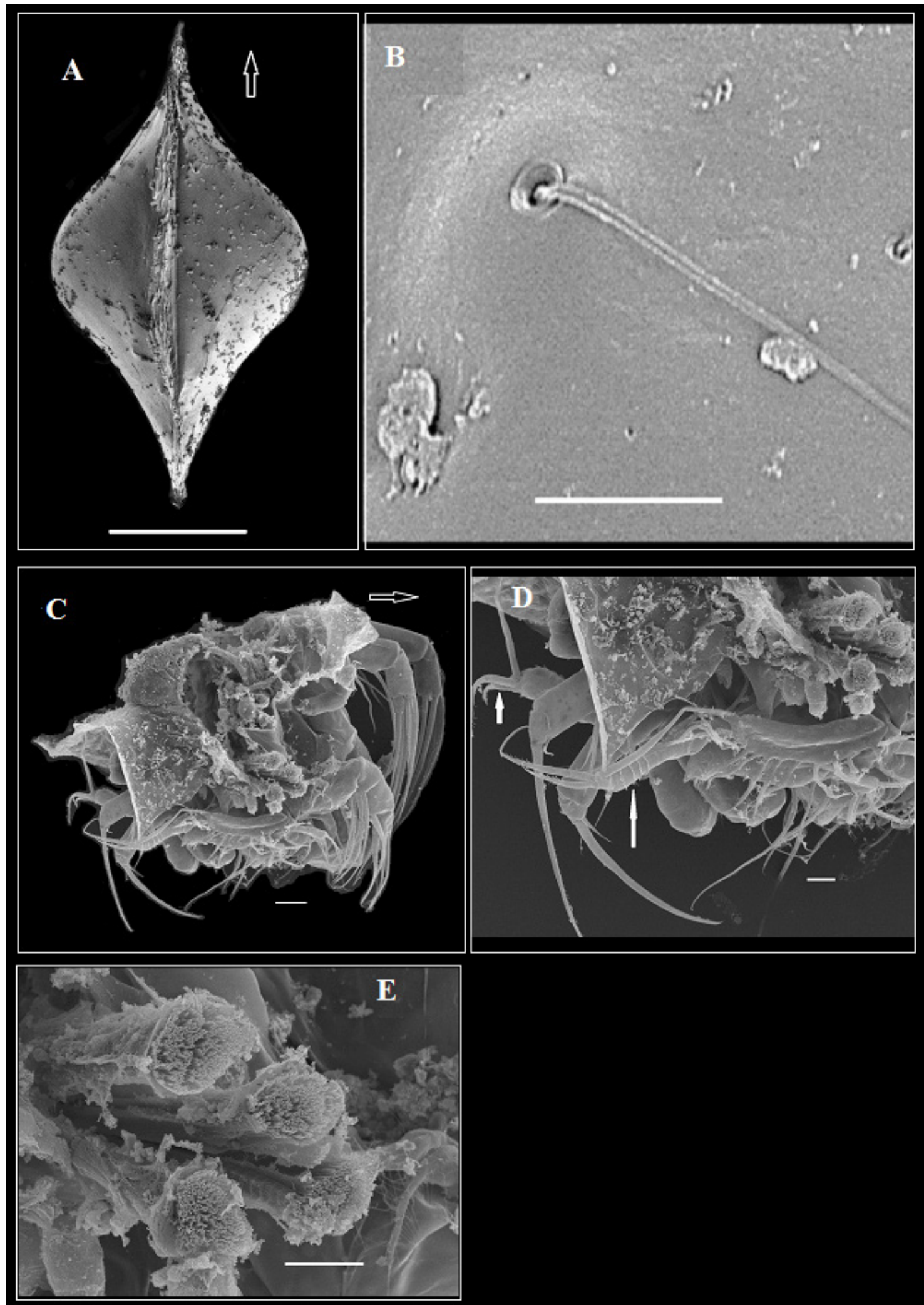

Fig. 3. Ufocandona hannaleeae gen. et sp. nov. A. Dorsal view of $\widehat{\partial}$ (arrow indicates anterior end). B. Normal pore opening with sensory seta. C. Soft body parts of $\widehat{\partial}$. D. Rear end of body, $\widehat{\delta}$; the thin arrow points to the four tiny setal groups on T3, the thick arrow to the distal end of T3. E. Ends of adductor muscles. Scale bars: $A=100 \mu \mathrm{m} ; \mathrm{B}=20 \mu \mathrm{m} ; \mathrm{C}-\mathrm{E}=10 \mu \mathrm{m}$. 
Ufocandona hannaleeae gen. et sp. nov. urn:1sid:zoobank.org:act:5CF0A5FB-F64F-45B5-837E-1BBCAB741D03

Figs $2-7$

\section{Diagnosis}

The species diagnosis is identical to that of the genus.

\section{Etymology}

The species name hannaleeae is in honor of Hanna Lee Sanborn, who is a steward of the San Marcos River and the Edwards Aquifer. The naming rights for this species were donated to the San Marcos River Foundation (SMRF) by the authors, as a fundraising item. Naming rights were purchased for Hanna Lee Sanborn by her fiancé, Matthew Erickson, at the 2016 SMRF annual meeting and silent auction, in honor of their engagement. All proceeds from the naming rights auction directly benefitted SMRF, a 501c3 non-profit organization whose mission is to "preserve and protect the natural beauty, flow, and purity of the San Marcos River", which is a spring-fed river derived from the Edwards Aquifer.

\section{Material examined}

\section{Holotype}

UNITED STATES OF AMERICA: $\hat{\alpha}$, Texas, Hays County, San Marcos artesian well (SMAW), 2953'22.46" N, 9756'11.27" E, 19 Nov. 2013, Benjamin F. Schwartz and Benjamin T. Hutchins leg. (OK-TX-AW049-01), all soft body parts dissected in lactophenol solution and sealed with translucent nail polish, valves in micropaleontological cavity slide (OK-TX-AW049-03).

\footnotetext{
Allotype

UNITED STATES OF AMERICA: + , collection data as for holotype (OK-TX-AW049-02), all soft body parts dissected in lactophenol solution and sealed with translucent nail polish, valves in micropaleontological cavity slide (OK-TX-AW051-04).

Paratypes

UNITED STATES OF AMERICA: $1 \hat{\jmath}$ (OK-TX-AW049-05), 2 우 (OK-TX-AW051-06), collection data as for holotype.
}

\section{Other material}

UNITED STATES OF AMERICA: 6 q $q, 4 \hat{\jmath} \hat{\jmath}, 3$ juv., collection data as for holotype, in $70 \%$ ethanol, deposited at the Limnology Laboratory, Department of Biology, Abant İzzet Baysal University, Bolu, Turkey.

\section{Description}

\section{Male}

Measurements. Holotype: $\mathrm{L}(\mathrm{LV})=0.442 \mathrm{~mm}, \mathrm{~L}(\mathrm{RV})=0.427 \mathrm{~mm}, \mathrm{H}(\mathrm{LV})=0.344 \mathrm{~mm}, \mathrm{H}(\mathrm{RV})=$ $0.312 \mathrm{~mm}$.

VALVES. LV overlaps RV from all sides (Fig. 2B). In lateral view, RV almost subtriangular in shape, with normal pore openings (Figs 2B, F, 3B). Dorsal margin of RV flat, sloping posteriorly. Both margins rounded, anterior margin more broadened than posterior. Greatest height located almost in middle of LV but located anteriorly on RV. Only LV with enlarged prolongation (flange) dorsally (diagnostic character). Valve surface mostly smooth at center but ornamented with hexagonal structures around marginal zones. Marginal zones of RV with dense tiny spines (Fig. 2C). Shallow pits and fine setae present in both sexes and juveniles. Central muscle scars not visible in external view (Fig. 2A-D) but visible in interior view (Fig. 3A-B). Hinge adont. Color translucent to opaque white. Eyes not observed or eye pigment absent. 
Viewed internally, anterior and posterior marginal areas of LV with 5-6 and 3-4 round tubercles on first list, respectively (diagnostic character). Second list shorter than first one. Calcified inner lamella almost equally wide at both ends, uncalcified inner lamella wide. In dorsal view, both ends thin and beakshaped, carapace laterally tumid, valves slightly concave ventrally (Figs 3A, 7B).

A1 (Fig. 4A). 8-segmented. First segment with one long, smooth apical seta on dorsal side of A1, reaching to end of second segment. Second segment with one medium-sized, smooth antero-distal seta at mid-length on dorsal side of segment, about half length of second segment. Rome organ absent. Wouters organ not seen. Third segment with small, apical (spine-type) seta on dorsal side. Fourth and sixth segments without setae. Fifth segment with two short (ca $1 / 4$ of segment) anterior and posterior

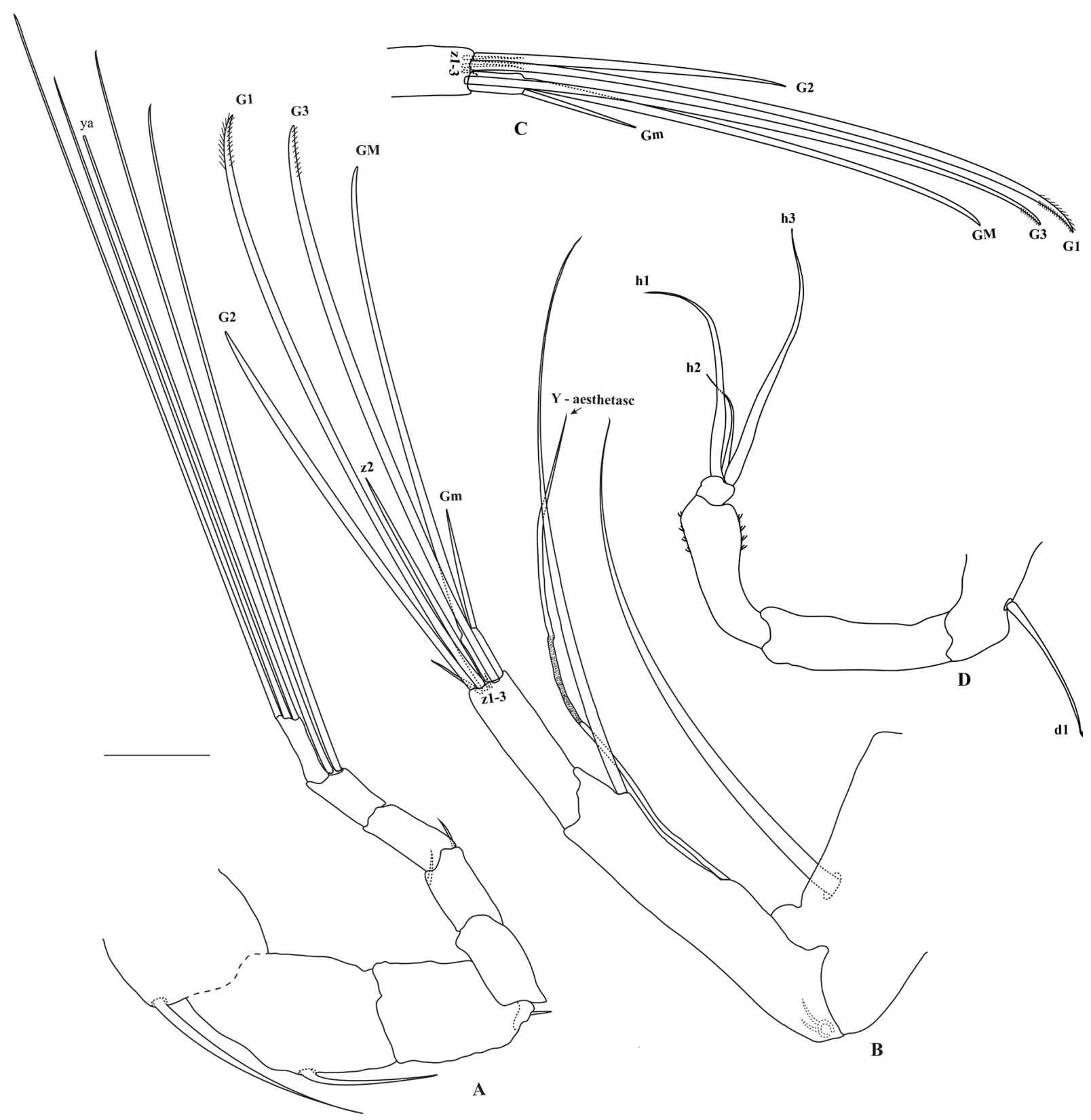

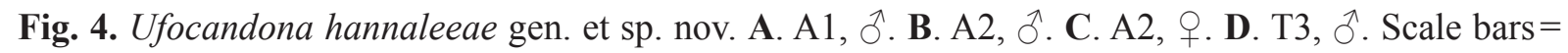
$25 \mu \mathrm{m}$. 
setae. Penultimate (seventh) segment with two very long antero-distal setae, approximately equal in length to all eight segments. Terminal segment with two equally long setae and one slightly shorter aesthetasc ya.

A2 (Fig. 4B). 4-segmented. Exopod with two very short setae (compare with female). First segment with long ventro-apical seta, approximately length of next three segments. Second segment with 2-segmented, long medio-ventral aesthetasc $\mathrm{Y}$ and one long seta, both of about same size and extending almost half length of terminal claws. t-setae absent. Third segment distally with three apically slightly plumose (G1), smooth (G2) or serrated (G3) claws; G2 claw slightly shorter than G1 and G3 claws, three z-setae (z1 and z3 short, z2 claw-like, almost reaching half of G2 claw) present, y1-y2 aesthetascs not seen. Terminal (fourth) segment with one long GM claw, about length of G3 claw, and one short Gm claw ( $1 \frac{1}{3}$ length of GM). Both claws smooth. Aesthetasc y3 not seen. Compare with A2 in female (Fig. 4C).

RAKE-LIKE ORGAN. Reduced, not seen well.

MD (Fig. 5A). Coxa well developed, with 8-9 spine-like teeth and 3 setae. Md-palp 4-segmented, without alpha, beta or gamma setae (diagnostic character). First segment with two medio-internal, long smooth setae about same length as segment. S1 and S2 setae smooth. Vibratory plate with about 7-8 setae, not seen well. Second segment anteriorly with $3+1$ setae, almost equal in size. Third (penultimate) segment ventro-apically with one well-developed, smooth, claw-like seta and a short seta. Terminal segment fused with terminal claw, carrying two well developed and slightly plumose claws.

MxL (Fig. 5B). Mxl-palp two segmented. First palp with smooth seta located ventro-apically. Terminal segment of Mxl palp very short, with two (one long and one short) smooth setae. Apical corner of first palp segment with two sharp, spine-like setae, slightly longer than other setae of terminal segment. Vibratory plate with about 14 slightly plumose filaments. Three lobes (endites), normal in shape, ending with 3, 4 and 4 smooth setae on first, second and third lobes, respectively. Base of first lobe with long seta extending to terminal palp.

T1 (Fig. 5C-D). Prehensile palp not segmented, both similar in size and modified into clasping organs, $3 \times$ as long as masticatory process. Anteriorly, palps ending with upper and lower parts. Upper part long, strongly curved anteriorly, ending with triangular apical part. Lower part thin and short, ending with short, tooth-shaped piece. One long b seta of about same length as masticatory part, other setae (a, c, d setae) absent. Masticatory process short, distally with 6 setae, $2 \times$ as long as masticatory part (see also Fig. 6D for female T1). Respiratory plate reduced to one tiny filament.

T2 (Fig. 5E). Five-segmented, with only one well-developed d1 seta on first segment (protopodite). Second, third and penultimate segments with one smooth, sub-apical (e, f, g) seta, anteriorly. Terminal segment with one very long, smooth claw (h2), extending to about end of second segment, and one very short h3 seta. Seta h1 missing.

T3 (Fig. 4D). 4 segmented with one medium size seta (d1) on the first segment (protopodite). Second segment long, about size of penultimate and terminal segments combined. Penultimate segment undivided (Fig. 3A), four groups of setules present dorsally (note: not seen internally; Fig. 3B). Three setae (e, f, and g) absent on segments 2-3. Terminal segment short, with three well-developed setae (h1-3). h3 slightly longer than h1. Seta h2 slightly curved and short, about half length of h3. Two long setae (h1 and h3) extending to second segment.

UROPOD. With thin, spine-like terminal seta, similar to flagellum-type uropod in subfamily Cypridopsinae, with thin, approximately cylindrical ramus. 
Hemipenis (Fig. 6B). Lobe a with triangular end, lobe $\mathrm{b}$ with broad end, lobe $\mathrm{h}$ rounded (diagnostic character). M-process large, with distal part (g) strongly curved.

ZENKER ORGAN (Fig. 6C). With 4+2 rings of spines, ending with sperm canal.

\section{Female}

Carapace similar in shape and size to that of male (Fig. 2A, E, 7A-B). Female (allotype): $\mathrm{L}=0.56 \mathrm{~mm}$, $\mathrm{H}=0.38 \mathrm{~mm}$. Average: $\mathrm{L}=0.473 \mathrm{~mm}(\mathrm{n}=3), \mathrm{H}=0.364 \mathrm{~mm}(\mathrm{n}=3), \mathrm{W}=0.245 \mathrm{~mm}(\mathrm{n}=2)$. T1 normally developed, with three h1-3 setae (Fig. 6D). Setae h1 and h3 almost equal in size and slightly shorter than h2. Exopod and exopodial setae on A2 not observed. All G claws (G1-G3, GM, Gm) present (Fig. 4C). z1-3 setae very small. Genital part very small, rounded and without genital process (Fig. 6A). One or two small, white to yellowish eggs visible in external view of carapace. All other soft parts similar to those of male.

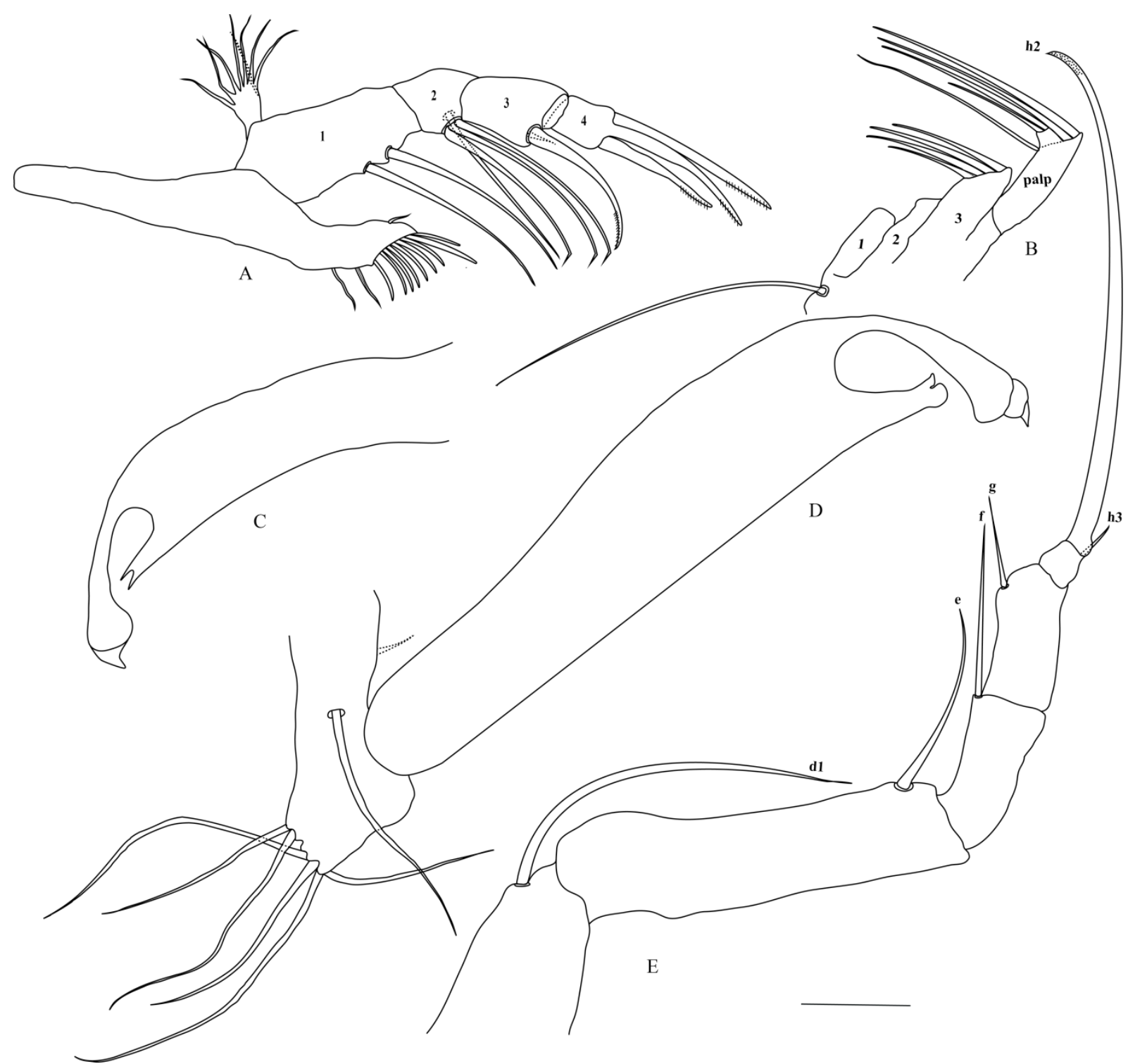

Fig. 5. Ufocandona hannaleeae gen. et sp. nov, ô. A. Md. B. Mxl. C-D. Left and right T1. E. T2. Scale bar: $\mathrm{A}-\mathrm{C}, \mathrm{E}=25 \mu \mathrm{m} ; \mathrm{D}=10 \mu \mathrm{m}$. 


\section{Ecology}

Ufocandona hannaleeae gen. et sp. nov. is known only from the type locality, where it occurs with 23 additional stygobionts, including a plethodontid salamander, two species of isopods, two species of decapods, a thermosbanacean, a planarian, three species of gastropods, a dytiscid beetle, a cyclopoid copepod, a hirudinean, and ten species of amphipods (Hutchins et al. 2014, 2016). However, the stygobiont fauna from this locality is incompletely known and also includes additional ostracod species, additional cyclopoid and harpacticoid copepods, aquatic mites, a bathynellid, and additional isopods and amphipods (Külköylüoğlu, Hutchins and Schwartz, pers. obs.), making the San Marcos artesian well one of the most biologically diverse groundwater sites on Earth (Holsinger \& Longley 1980; Culver \& Pipan 2009). The lack of pigment, relatively thin carapace, reduced eyes and reduction of many setae (see above description) suggest that Ufocandona hannaleeae gen. et sp. nov. is also a stygobiont.

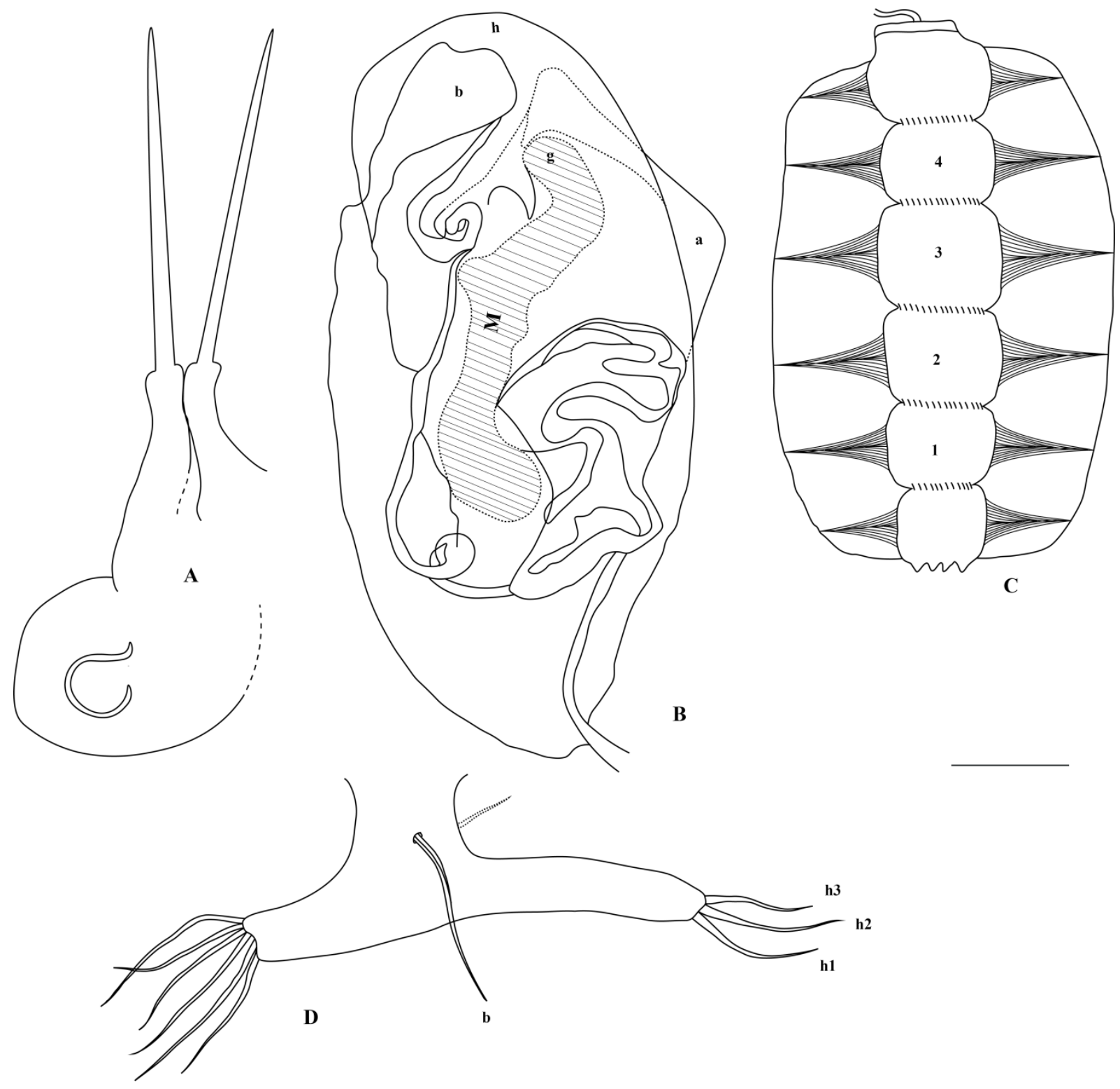

Fig. 6. Ufocandona hannaleeae gen. et sp. nov. A. Ur with female genital organ. B. Hemipenis. C. Zenker's organ. D. T1. A, D: $ᄋ$; B, C: ${ }^{\lambda}$. Scalebar $=10 \mu \mathrm{m}$. 
Species at the San Marcos artesian well utilize diverse carbon sources derived in part from chemolithoautotrophic production occurring along a freshwater-saline water interface along the downdip edge of the Edwards Aquifer (Hutchins et al. 2016). Primary productivity has played an important role in the evolution and maintenance of the longest subterranean food chain currently known (Hutchins \& Schwartz 2013), and species partition food resources (Hutchins et al. 2014, 2016). Furthermore, invertebrate species from the San Marcos artesian well display a diversity of body morphologies, and the relative abundance of species varies substantially in response to precipitation (Hutchins and Schwartz, pers. obs.). These suggest a heterogeneous environment comprised of a mosaic of microhabitats. However, there is currently no detailed information about habitat preference or trophic ecology for Ufocandona hannaleeae gen. et sp. nov. Because species of the subfamily are not able to swim, due to the absence of swimming setae on A2, Ufocandona hannaleeae gen. et sp. nov. is probably an obligate benthic species inhabiting sediments, rock surfaces or biofilms. Of the nearly 12000 ostracods collected from this site, less than 20 belong to Ufocandona hannaleeae gen. et sp. nov. This may be due to relative rarity or, because it does not swim, the species may only rarely be expelled from the well. The remaining individuals are the subject of ongoing study and results will be presented elsewhere.

\section{Distribution}

Known only from the type locality.

\section{Discussion}

\section{Taxonomic affinities}

Ufocandona gen. nov. can be tentatively placed in the tribe Candonopsini Karanovic, 2004 based on the absence of swimming setae on A2, absence of a posterior seta on the uropod, presence of rows of

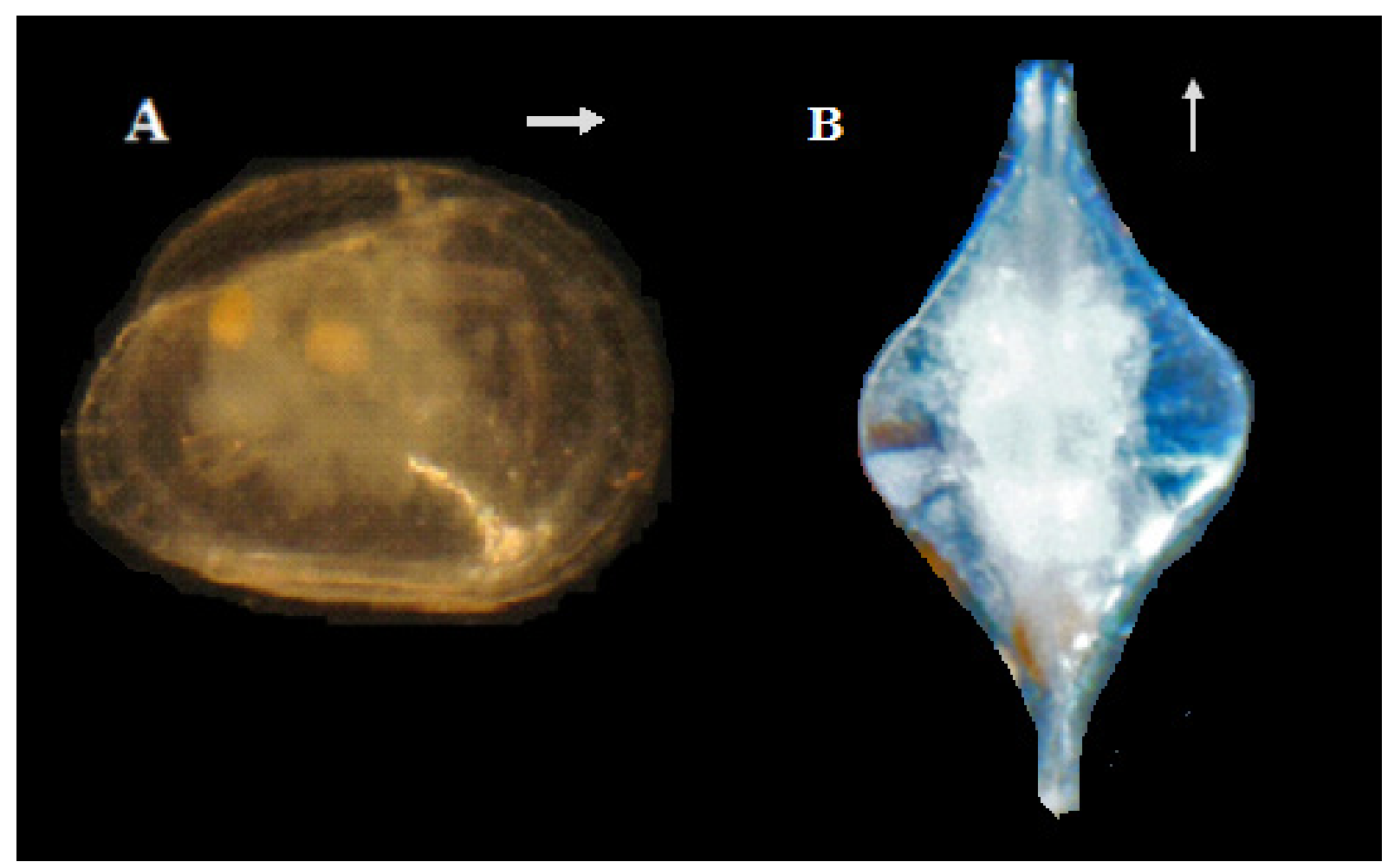

Fig. 7. Ufocandona hannaleeae gen. et sp. nov., ․ . A. External view of carapace from right side (note the dorsal flange on LV). B. Carapace in dorsal view. Both in transmitted light. Not to scale. 
spines on the Zenker's organ and the normal pore canals with sensory setae. These characters can also be found in some other genera of this tribe (Candonopsis Vávra, 1891; Caribecandona Broodbakker, 1983; Cubacandona Broodbakker, 1983; Marococandona Marmonier et al., 2005; Pioneercandonopsis Karanovic, 2005; Latinopsis Karanovic \& Datry, 2009; Candobrasilopsis Higuti \& Martens, 2012). For example, normal pore canals with sensory setae (Figs 2A-B, 3B) are present in almost all species of the genera.

Ufocandona gen. nov. displays several morphological characteristics that distinguish it from other genera (e.g., Bicornucandona Külköylüoğlu et al., 2011; Indocandona Gupta, 1984; Candonopsis; Areacandona Karanovic, 2005; Meischcandona Karanovic, 2001). The characters which clearly distinguish the new genus from others include the centrally tumid shape of the carapace in dorsal view, with both ends of left and right valves thin, beak-shaped, and slightly concave ventrally (Fig. 2), the presence of a dorsal prolongation on LV, the hexagonal ornamentation around the marginal zones, with 3-6 round tubercles seen from the inside of LV (Fig. 2E), dense spines around the marginal zones of RV, a broad, calcified inner lamella, an 8-segmented A1, a long Y aesthetasc on A2, the absence of t1-4 setae, two short or reduced (in females) exopodial setae on A2, the absence of setae (alpha, beta and gamma) on the Md palp, asymmetric clasping organs in males, the presence of one $\mathrm{d} 1$ seta on $\mathrm{T} 2$ and $\mathrm{T} 3$, the flagellum- or spine-like uropod, and the shape of the hemipenis.

The asymmetric valves of the carapace display distinct diagnostic characteristics of Ufocandona gen. nov. Danielopol (1980) reported species (e.g., Mixtacandona sp. in Danielopol \& Cvetkov 1979 and Pseudocandona dorsoconcava Bronshtein, 1947) with conspicuous dorsal protuberances, but none of them are similar to those of the new genus because of differences in the shape, location and type of these prolongations.

Hexagonal ornamentation around the marginal zones of both valves, but mostly lacking in the center, also distinguishes Ufocandona gen. nov. from congeners. This ornamentation is abundant on the prolongation of the LV. A similar hexagonal ornamentation can be seen in a few ostracod species (e.g., Mixtacandona pietrosanii Danielopol \& Cvetkov, 1979) in different tribes, but there are differences between $M$. pietrosanii and Ufocandona hannaleeae gen. et sp. nov. For example, the former species has a triangular shape (Danielopol \& Cvetkov 1979) while the latter has a subtriangular to oval shape (this study). Additionally, the ornamentation is distributed mostly dorsally, while it is placed almost all around the marginal zones of the latter species. The presence of round tubercles on the internal side of the LV of the carapace (Fig. 2E) is also unique to Ufocandona gen. nov. within the tribe Candonopsini.

The A1 in Ufocandona gen. nov. is 8-segmented, but in other members of the tribe the number of segments on A1 are 7 or less (Karanovic 2005a, 2005b, 2005c, 2012). For example, A1 is 7-segmented in the genera Candonopsis, Cubacandona, Latinopsis, and Candobrasilopsis, 6-segmented in Caribecandona, 6- or 7-segmented in Marococandona and 4-segmented in Pioneercandonopsis (Broodbakker 1983; Karanovic 2005c; Karanovic \& Datry 2009; Higuti \& Martens 2012). In some other genera (Meischcandona; Nannocandona; Humphreyscandona Karanovic \& Marmonier, 2003; Pilbaracandona Karanovic \& Marmonier, 2003; Notacandona Karanovic \& Marmonier, 2003) of the Candoninae, A1 is 5-segmented (Karanovic 2001, 2005b; Karanovic \& Marmonier 2003). The antennule of the endemic Japanese genus Undulacandona Smith, 2011 bears 6 segments (Smith 2011).

The absence of an exopod on the A2 of females and the presence of two very thin setae on the A2 of males are important to mention here, since they are important characters distinguishing Ufocandona gen. nov. from other genera of the family Candonidae. Most of these genera possess an exopod with one long and two short setae, exceptions being an exopod on A2 with 1 minute seta in, e.g., Danielocandona 
Broodbakker, 1983, or with 3 minute setae in, e.g., Trajancandona Karanovic, 1999, Leicacandona Karanovic, 2007 (see Karanovic 2012) and Undulacandona Smith, 2011. This is indeed important considering that even though the exopod may be reduced, with a plate and two or three setae, it is present in almost all members of the tribe Candonopsini. According to Karanovic (pers. comm.), a reduced exopodite seems to be convergent in several candonid lineages (e.g., Trajancandona, Undulacandona and possibly several species from Australian subterranean waters). This may be an adaptation to subterranean waters. However, since the exopod is not completely missing in Ufocandona gen. nov., its evolutionary development should not be generalized at the moment. The presence or absence of an exopod is not commonly used in taxonomic keys. However, given the differences discussed above, the inclusion of this important character state in keys should be considered. Additionally, the absence of t-setae (t1-4) on A2 in Ufocandona gen. nov. is important to consider; these setae are present and of normal size in some members of the Candonidae (e.g., Bicornucandona; Külköylüoğlu et al. 2011) and/or transformed into bristles in the males of some other genera (e.g., Candonopsis (Abcandonopsis) Karanovic, 2004; Acandona Karanovic, 2003 (Karanovic 2003b, 2007, 2012); Indocandona (Gupta 1984; Karanovic \& Ranga Reddy 2008); Undulacandona (Smith \& Kamiya 2015)).

A few genera are known that have one claw on the uropod. Members of the genus Indocandona, from subterranean waters in Bahir, India (Gupta 1984) and southern India (Karanovic \& Ranga Reddy 2008) possess a short ramus and a long distal claw. Candonopsis (A.) aula Karanovic, 2004 also possesses a uropod similar in shape to that seen in Indocandona Gupta, 1984. In contrast, Bicornucandona, from spring waters in Texas (USA), bears a well-developed uropod with a strong ramus, two claws, and anterior and posterior setae (Külköylüoğlu et al. 2011). In all of these cases, either the claws or the rami or both are relatively well developed. However, Ufocandona gen. nov. possesses one complete (ramus and claw not separated; Fig. 6A), weakly developed, flagellum-like uropod, whereas in all other members of the family, the uropod may lack posterior setae, but the posterior claw is well developed, reduced or sometimes missing (Meisch 2000; Karanovic 2001; Karanovic \& Lee 2012).

The terminal segment of the Md in Ufocandona hannaleeae gen. et sp. nov. is fused with the terminal claw and has two well developed and slightly plumose claws. In contrast, the mandibula of most (if not all) genera of the tribe Candonopsini (and Candonini Kaufmann, 1900) bears a long terminal claw that is fused with the apical segment. Furthermore, the absence of $\alpha, \beta$ and $\gamma$ setae on the Md palps is unique to Ufocandona gen. nov. within the tribe. It is also known that the first segment of the Md palp usually bears two plumose S1 and S2 setae. In the new genus two smooth setae are found in a similar location on the Md. Thus, at the moment, although we assume them to be S1 and S2 setae, the homologies of these two setae are not clear. The L:W ratio of the terminal segment shows substantial variation among genera. In Ufocandona gen. nov. and Acandona (e.g., A. admiratio; see Karanovic 2003b), the ratio is about $1: 1$. However, it is $3: 1$ or larger in the genus Candonopsis (Karanovic \& Petkovski 1999; Karanovic 2004 but 2:1 or less in Meridiescandona Karanovic, 2003 and Deminutiocandona Karanovic, 2003 (Karanovic 2003a).

Additionally, the hemipenis and T1 of Ufocandona hannaleeae gen. et sp. nov. differ in their shape. For example, the outer lobe is well developed and triangular to square in shape while the medial lobe is large and oval, and the inner lobe enlarged ventrally. Also, the distal part of the M-process of the hemipenis is strongly curved. The T1 palp (endopod) consists of one piece and is not segmented. Its length is 3 or more times as long as that of the masticatory process. Such a long palp is common among members of the tribe. However, the T1 bears a single b-seta on the protopodite, while other setae (a, c, and d setae) are absent in Ufocandona gen. nov. As far as we know, other members of the subfamily Candoninae have at least two of these setae on the masticatory process. 


\section{Taxonomic conclusions}

Taxonomic similarities suggest that Ufocandona gen. nov. belongs to the subfamily Candoninae. However, as discussed above, Ufocandona hannaleeae gen. et sp. nov. shows several unique morphological characteristics at the tribe level. As discussed in an excellent review by Danielopol et al. (2011), taxonomic difficulties remain in the family Candonidae, and additional studies are needed to better resolve the taxonomic relationships among species within the family. The lack of body color, relatively thin carapace, reduced eyes and reduction on some setae (e.g., on the exopodial part) suggest that species of Candonidae, found primarily in wells, springs, and other subsurface aquatic waters, are adapted to groundwater conditions. However, because of the inaccessibility of groundwater habitats and a lack of taxonomic attention, the global diversity of groundwater Candonidae is poorly known and further studies are needed to fill in the missing pieces of the puzzle.

\section{Conclusions}

We propose that Ufocandona gen. nov. with its type species, Ufocandona hannaleeae gen. et sp. nov., differs from other genera within the subfamily Candoninae based on the presence of a protrusion on its left valve, the asymmetry between the valves, its tubercles and hexagonal ornamentations, hemipenis, flagellum or rod-like uropod, and the different shape and numbers of setae on the appendages, as well as their location on the soft body parts. The number of genera within the Candonidae is now increased to eight, with 42 species in North America, 28 of which are endemic to the continent.

\section{Acknowledgements}

We thank Prof. Ivana Karanovic (Hanyang University) for sharing her ideas about the absence of an exopod on A2. We also thank Cem Berk (TÜBİTAK - MAM) for his help with SEM photography. Weston Nowlin, Zachary Schwartz, Jonny Scalise and Aaron P. Swink assisted with sorting raw samples and counting ostracods.

\section{References}

Broodbakker N.W. 1983. The subfamily Candoninae (Crustacea, Ostracoda) in the West Indies. Bijdragen tot de Dierkunde 53 (2): 287-326.

Broodbakker N.W. \& Danielopol D.L. 1982. The chaetotaxy of Cypridacea (Crustacea, Ostracoda) limbs: proposals for a descriptive model. Bijdragen tot de Dierkunde 52 (2): 103-120.

Culver D.C. \&. Pipan T. 2009. The Biology of Caves and other Subterranean Habitats. Oxford University Press, Oxford, UK.

Danielopol D.L. 1980. On the carapace shape of some European freshwater interstitial Candoninae. Proceedings of the Biological Society of Washington 93: 743-756.

Danielopol D.L. \& Cvetkov L. 1979. Trois nouvelles espèces du genre Mixtacandona. Hydrobiologia 67: 249-266. https://doi.org/10.1007/BF00023181

Danieolopol D.L., Baltanás A., Morocutti U. \& Österreicher F. 2011. On the need to renew the taxonomic system of the Candoninae (non-marine Ostracoda, Crustacea). Reflexions from an analysis of data using the Yule Process. Geo-Eco-Marina 17: 195-210.

Danielopol D.L., Namiotko T. \& Meisch C. 2012. Marmocandona nov. gen. (Ostracoda, Candoninae), with comments on the contribution of stygobiotic organisms to micropalaentological studies. In: Viehberg F.A. \& Gromig R. (eds) Abstracts, $14^{\text {th }}$ International German Ostracodologists' Meeting, Cologne. Kölner Forum für Geologie und Paläontologie 21: 13-16. 
Gupta L.P. 1984. Indocandona krishnakanti gen. et sp. nov. (Crustacea: Ostracoda: Candonidae) from subterranean water of Bihar. Records of the Zoological Survey of India 8: 291-298.

Higuti J. \& Martens K. 2012. Description of a new genus and species of Candonopsini (Crustacea, Ostracoda, Candoninae) from the alluvial valley of the Upper Paraná River (Brazil, South America). European Journal of Taxonomy 33: 1-31. https://doi.org/10.5852/ejt.2012.33

Holsinger J.R. \& Longley G. 1980. The subterranean amphipod crustacean fauna of an artesian well in Texas. Smithsonian Contributions to Zoology 308: 1-62.

Hutchins B.T. \& Schwartz B.F. 2013. Food chain length in groundwater: patterns in $\delta 15 \mathrm{~N}$ range. Proceedings of the 16 ${ }^{\text {th }}$ International Congress of Speleology 2013: 403-40.

Hutchins B.T., Schwartz B.F. \& Nowlin W.H. 2014. Morphological and trophic specialization in a subterranean amphipod assemblage. Freshwater Biology 59: 2447-2461.

https://doi.org/10.1111/fwb.12440

Hutchins B.T., Engel A.S., Nowlin W.H. \& Schwartz B.F. 2016. Chemolithoautotrophy supports macroinvertebrate food webs and affects diversity and stability in groundwater communities. Ecology 97 (6): 1530-1542. https://doi.org/10.1890/15-1129.1

Karanovic I. 2001. Meischcandona gen. nov. from Africa, with a key to the genera of the subfamily Candoninae (Crustacea, Ostracoda). Bulletin de l'Institut Royal des Sciences Naturelles de Belqique, Sciences de la Terre 71: 93-99.

Karanovic I. 2003a. Towards a revision of Candoninae (Crustacea: Ostracoda): description of two new genera from Australian groundwaters. Species Diversity 8: 353-383.

Karanovic I. 2003b. A new genus of Candoninae (Crustacea, Ostracoda, Candonidae) from the subterranean waters of southwestern Western Australia. Records of the Western Australian Museum 21: 315-332.

Karanovic I. 2004. Towards a revision of Candoninae (Crustacea, Ostracoda): on the genus Candonopsis Vávra, with descriptions of new taxa. Subterranean Biology 2: 91-108.

Karanovic I. 2005a. Towards a revision of Candoninae (Crustacea: Ostracoda): Australian representatives of the subfamily, with descriptions of three new genera and seven new species. New Zealand Journal of Marine and Freshwater Research 39: 29-75. https://doi.org/10.1080/00288330.2005.9517292

Karanovic I. 2005b. Comparative morphology of the Candoninae antennula, with remarks on the ancestral state in ostracods (Crustacea, Ostracoda) and proposed new terminology. Spixiana 28 (2): 141-160. Available from https://biodiversitylibrary.org/page/28192323 [accessed 27 Oct. 2017].

Karanovic I. 2005c. A new Candoninae genus (Crustacea: Ostracoda) from subterranean waters of Queensland, with a cladistic analysis of the tribe Candonopsini. Memoirs of the Queensland Museum 50: 303-319.

Karanovic I. 2006. Recent Candoninae (Crustacea, Ostracoda, Candonidae) of North America. Records of the Western Australian Museum Suppl. 71: 1-75.

https://doi.org/10.18195/issn.0313-122x.71.2006.001-075

Karanovic I. 2007. Candoninae (Ostracoda) from the Pilbara Region in Western Australia. Crustaceana Monographs 7: 1-434.

Karanovic I. 2012. Recent Freshwater Ostracods of the World: Crustacea, Ostracoda, Podocopida. Springer Publishing, Heidelberg, Germany. 
Karanovic I. 2013. Earicandona, new genus and the first record of Typhlocypris pratensis (Crustacea, Ostracoda) from South Korea. Journal of Species Research 2: 145-158.

https://doi.org/10.12651/JSR.2013.2.2.145

Karanovic I. \& Datry T. 2009. Overview of Candoninae (Crustacea, Ostracoda) of South America and the West Indies, with the description of two new species and one new genus. Zootaxa 2267: 1-25.

Karanovic I. \& Lee W. 2012. A review of candonid ostracods (Crustacea: Ostracoda: Podocopida) from East Asia, with descriptions of five new species from South Korea. Zootaxa 3368: 7-49.

Karanovic I. \& Marmonier P. 2003. Three new genera and nine new species of the subfamily Candoninae (Crustacea, Ostracoda, Podocopida) from the Pilbara Region (Western Australia). Beaufortia 53 (1): $1-51$.

Karanovic I. \& Petkovski T. 1999. Two new species of the subfamily Candoninae (Ostracoda) from Montenegro (SE Europe). Crustaceana 72: 603-616. https://doi.org/10.1163/156854099503645

Karanovic I. \& Ranga Reddy Y. 2008. The second representative of the genus Indocandona gupta (Ostracoda) from a well in Southeastern India. Crustaceana 81 (7): 861-871. https://doi.org/10.1163/156854008784771649

Krömmelbein K. 1975. Ostracoden aus der Kreide des Great Artesian Basin, Queensland, Australien. Senckenbergiana Lethaea 55: 455-483.

Külköylüoğlu O. 2009. Ecological succession of freshwater Ostracoda (Crustacea) in a newly developed rheocrene spring (Bolu, Turkey). Turkish Journal of Zoology 33 (2): 115-123.

https://doi.org/10.3906/zoo-0712-12

Külköylüoğlu O., Gibson R., Diaz P.H. \& Colin J.P. 2011. Bicornucandona gen. nov., sp. nov. (Crustacea, Ostracoda) from Finegan Springs (Texas, U.S.A.). Zootaxa 3059: 47-58.

Külköylüoğlu O., Yavuzatmaca M., Akdemir D., Diaz P.H. \& Gibson R. 2017. On Schornikovdona gen. nov. (Ostracoda, Candonidae) from rheocrene springs in Texas (U.S.A.). Crustaceana 90 (11-12): 1443-1461. https://doi.org/10.1163/15685403-00003707

Martens K. 1987. Homology and functional morphology of the sexual dimorphism in the antenna of Sclerocypris Sars, 1924 (Crustacea, Ostracoda, Megalocypridinae). Bijdragen tot de Dierkunde 57: 183-190.

Martens K. \& Savatenalinton S. 2011. A subjective checklist of the Recent, free-living, non-marine Ostracoda (Crustacea). Zootaxa 2855: 1-79.

Meisch C. 2000. Freshwater Ostracoda of Western and Central Europe. Süsswasserfauna von Mitteleuropa 8/3. Spektrum Akademischer Verlag/ Gustav Fischer, Heidelberg, Germany.

Namiotko T., Danielopol D.L., Meisch C., Gross M. \& Mori N. 2014. Redefinition of the genus Typhlocypris Vejdovský, 1882. Crustaceana 87: 952-984.

https://doi.org/10.1163/15685403-00003338

Ogden A.E., Quick R.A. \& Rothermel S.R. 1986. Hydrochemistry of the Comal, Hueco, and San Marcos Springs, Edwards Aquifer, Texas. In: Abbott P.L. \& Woodruff Jr C.M. (eds) The Balcones Escarpment: Geology, Hydrology, Ecology and Social Development in Central Texas: 115-131. Geological Society of America, San Antonio, Texas.

Ponder W.F. 2004. Endemic aquatic macroinvertebrates of artesian springs of the Great Artesian Basinprogress and future directions. Records of the South Australian Museum Monograph Series 7: 101-110. 
Smith R.J. 2011. Groundwater, spring and interstitial Ostracoda (Crustacea) from Shiga Prefecture, Japan, including descriptions of three new species and one new genus. Zootaxa 3140: 15-37.

Smith R.J. \& Kamiya T. 2015. Four new species of the subfamily Candoninae (Crustacea, Ostracoda) from freshwater habitats in Japan. European Journal of Taxonomy 136: 1-34.

https://doi.org/10.5852/ejt.2015.136

Manuscript submitted: 6 December 2016

Manuscript accepted: 20 June 2017

Manuscript published: 30 November 2017

Topic editor: Rudy Jocqué

Desk editor: Danny Eibye-Jacobsen

Printed versions of all papers are also deposited in the libraries of the institutes that are members of the EJT consortium: Muséum national d'Histoire naturelle, Paris, France; Botanic Garden Meise, Belgium; Royal Museum for Central Africa, Tervuren, Belgium; Natural History Museum, London, United Kingdom; Royal Belgian Institute of Natural Sciences, Brussels, Belgium; Natural History Museum of Denmark, Copenhagen, Denmark; Naturalis Biodiversity Center, Leiden, the Netherlands; Museo Nacional de Ciencias Naturales-CSIC, Madrid, Spain; Real Jardín Botánico de Madrid CSIC, Spain. 